\title{
Towards a whole-school approach to the pastoral care module in a Postgraduate Certificate of Education programme: a South African experience
}

Sonja Schoeman

Department of Curriculum and Instructional Studies, University of South Africa, Pretoria, South Africa

\begin{abstract}
This study explores the potential of adopting a whole-school approach to the pastoral care module in a Postgraduate Certificate of Education Programme to ensure that all newly qualified teachers practice effective pastoral care in their classrooms and promote the learners' academic engagement and performance. A non-experimental survey research design involving quantitative data was used. A group-administered questionnaire was used to collect the sampled student teachers' $(n=59)$ opinion on the competencies they obtain from the module. The student teachers ranked knowledge first, beliefs and values second, and skills third. For the student teachers to perform their academic and pastoral roles constructively together in a challenged education system, it is recommended that, in the short term, a learning unit, which is grounded in Best's (1990) needs-focused model of pastoral care, be included in the module; and, in the long term, given the context of the South African schooling system, the nurturer professional model of teacher education be implemented.
\end{abstract}

Keywords: academic engagement and performance; integrated academic and pastoral roles; pastoral care; pre-service teachers; whole-school approach

\section{Introduction}

Pastoral care has been part of the South African education system for many years. The concept originated in England in the 19th century; and was closely related to the Christian religious philosophy. Teachers facilitated the moral welfare and ethical self-development of the learners using extra-curricular activities in schools. In most South African schools pastoral care continues to be position-oriented, and associated with notions of help, advice and moral guidance. Pastoral care in this context is usually separated from and complementary to academic learning. Over the past three decades however, interest has intensified in a whole-school approach to pastoral care which supports the holistic development of learners (Chidester 2006; Hearn, Campbell-Pope, House, and Cross 2006). Research findings confirm the advantages of integrated planning to meet the personal, emotional, social and academic needs of learners through a pastoral care approach which is integrated in the academic curriculum and the structural organisation of the school (Clark 2008; De Jong and Kerr-Roubicek 2007; Department of Education 2003; Eacute and Esteve 2010; Hui 2002; Scott 2005).

\section{Problem of the study}

The problem highligted in this study focuses on the academic/pastoral divide in South African classrooms, and the factors inside and outside the classroom and school which effect the learners' academic engagement and achievement. During teaching practice, and early in their teaching careers, teachers are exposed to two sides of the school: the pastoral side, which provides a caring, nurturing environment in which learners are meant to grow as individuals; and 
the academic side, which facilitates the teaching and learning of school subjects. However, in terms of the education policy documents, teachers are not only expected to know their subject and facilitate the learning thereof, but also to be responsible for the pastoral well-being of the learners in their classrooms (Department of Basic Education 2011; Department of Education 2003; Ministry of Education 2007; Republic of South Africa 2011). The integrated needs of learners are acknowledged in the literature dealing with the teaching and learning of the school subjects, but in reality South African teachers are wearing two hats, an academic hat and a pastoral hat. Learners are viewed as either recipients of an academic curriculum; or as a person requiring pastoral care, rather than an individual with integrated needs. The pastoral care of learners is often neglected (School visits 2011).

The typical characteristics of public schools in South Africa give credence to the thesis that South Africa comprises "two nations" - one that is rich, predominantly middle class and urban-based, and one that is poor and inner city- and rural-based. The challenge is to provide learners in the deprived areas with equal access to education. According to Hunter-Gault (2008) and Phurutse (2005), factors which effect these learners' academic engagement and performance are among others overcrowded and under-resourced classrooms; under-qualified, unaccountable teachers; mismanagement of resources; impoverished communities and unemployment. The education context plays a major role in the educational engagement and performance of learners, but the agency of the learners, teachers, parents and community play an equally critical role in transcending the poor conditions to achieve good results. Dugmore (Ministry of Education 2007) declared that: 'Too many learners ... with the potential to reach Grade 12 are not making it ... , and are leaving the system'. He encouraged teachers to be committed and to inspire learners to reach the target for matriculation endorsement and passes. He stressed that an action plan was needed to support the learners, and emphasised that it was not the responsibility of teachers alone, but should include both the parents and the community. He explained that a whole-school approach to pastoral care was needed to increase the schools' impact on learning. Therefore, the academic and pastoral roles of the teacher would have to become intermeshed, where the sense of knowing the whole learner as a person is linked to following the learner's academic performance (Lodge 2006; Republic of South Africa 2011; Watkins 1999).

\section{Research objectives}

This study set out to determine what higher education institutions in South Africa will have to do to link this new pastoral care responsibility of teachers to their didactics modules to equip prospective teachers for the complex professional task and wide-ranging responsibilities with which they are presently charged. The study surveyed PGCE students' opinion (at one higher education institution) on the competencies (knowledge, skills, beliefs and values) they obtained from a pastoral care module; and explored the potential of adopting a whole-school approach to the module to ensure that qualified teachers practice effective pastoral care in their classrooms, and improve the learners' academic engagement and performance, throughput, and, ultimately, the equal development of all human beings in South Africa.

\section{Research questions}

Three research questions were formulated, namely RQ1: What are the student teachers' opinion on the competencies (knowledge, skills, beliefs and values) they obtain from the pastoral care 
module at the higher education institution under study? RQ2: To what extent was there a match between the pastoral care module and the whole-school approach to pastoral care? and RQ3: How can the pastoral care module be redefined to constructively bring together the academic and pastoral roles of teachers to facilitate effective pastoral care in their classrooms?

\section{Review of the literature}

\section{The concept pastoral care}

From an etymological perspective, the term pastoral care suggests the idea of nurturing or feeding people (Clark 2008). Best and Lang (1995) and Marland (1974) suggest that the term covers the non-instructional aspects. Nadge (2005) pointed out that the definition of pastoral care has recently taken on a more inclusive function. It is inextricably linked to the academic curriculum and the structural organisation of the school (the whole-school approach to pastoral care), thereby promoting learners' personal and social development and fostering positive attitudes through the quality of teaching and learning; nature of relationships amongst learners, teachers and adults other than teachers; arrangements for monitoring learners' overall progress, academic, personal and social; specific pastoral and support systems; extra-curricular activities and the school ethos.

\section{Conceptual framework of the study: The needs-focused model}

According to Best (1990), learners in schools have three types of needs. First, there are those needs which have primarily to do with the fact that they lack maturity and experience. As learners they need security, guidance, moral support and love. The unconditional acceptance conventionally associated with the ideal of parental love is important in meeting such needs. The teacher may, on two counts, be responsible for providing some comparable (if less intimate) support: as the moral duty of any responsible adult in the company of minors; and, as the professional duty of the teacher in loco parentis. The individualised care provided by the teacher to know, guide, support, comfort and counsel learners is termed the pastoral casework (Best 1990).

Second, there are those needs which are primarily to do with the role of the child or adolescent as a learner. Learners need opportunities to acquire concepts, learn facts, practise skills, develop attitudes, explore feelings, reflect on beliefs and examine values. They need relevant and appropriate learning experiences, organised and presented in ways which take account of their capabilities, the structure of knowledge and the relationships between knowledge, skills and understanding. Hence, there is content to pastoral care as much as there is to any other subject. The part of the school curriculum which has distinctively to do with the personal and social development of the learner as opposed to his/her academic development is termed the pastoral curriculum (Best 1990).

Third, there is needs which follow from the requirements of social order. Without order no learner can develop, least of all in terms of personal and social development. According to Best (1990), since the "self" can only be produced through social interaction, objectives such as self-awareness, self-criticism and self-control are impossible without an ordered set of social relationships. Schools should not be satisfied to meet the minimal conditions of a society; but should aim to be communities. The needs of the learner as a "citizen" of a school community are 
among others to engage in corporate activities; participate in decision-making; feel a sense of belonging, common destiny and mutual concern for the well-being of the other "citizens"; experience a framework of rules that protect the liberty of the individual from the excessive behaviour of others; and a system of sanctions to ensure that rules are followed. This category of needs is termed the pastoral care control (Best 1990).

For the coordination of the above three categories, a different category of pastoral activities, termed the pastoral management, is needed. This category is not concerned with the needs of the learners directly, but the facilitation and support of the needs of the teachers in fulfilling their pastoral care role effectively (Best 1990).

\section{The whole-school approach to pastoral care}

The concept of a whole-school approach to pastoral care entails a positive, flexible, comprehensive systems framework developed in consultation with learners, teachers and parents. It must be designed to prevent problems through the provision of clear, consistent and agreed systems, policies and procedures. It can include a tiered approach, addressing issues at school, classroom and individual levels. This approach is most effective when underpinned by a set of principles agreed to and promoted by the school community, such as inclusion, belonging, relationship building and collaboration. It also involves assessment of the school environment and application of positive interventions and systems across the school in an attempt to create positive learning and teaching environments, and to reduce problems. The most important feature of this approach is its comprehensive nature to provide the differing levels of intervention required in a school to affect all areas of need (Doig 2000; Eber, Sugai, Smith, and Scott 2002; Gaffney, McCormack, Higgins, and Taylor 2004; Nelson, Martell, and MarchandMartella 2002).

The literature describes three key principles of an effective whole-school approach to pastoral care, namely belonging, relationships and engagement. According to Baumeister and Leary (cited in Fredericks, Blumenfeld, and Paris 2004:80), the principle belonging is described as '.. an individual's sense of being accepted, valued, included and encouraged by others'. Osterman (2000) concludes that learners' experiences of belonging are linked to a positive orientation towards the school, class work and teachers, and higher academic engagement and achievement. Learners who have a sense of belonging demonstrate a stronger sense of identity, autonomy, intrinsic motivation, acceptance of authority and responsibility to control their behaviour. Relationships are the key principle for establishing a sense of belonging. The establishment of positive, supportive and collaborative relationships between the teachers is an important precursor to examining and improving the relationships between the teachers and the learners, and between the learners (Certo, Cauley, and Chafin 2003; Doig 2000; Gaffney et al. 2004). According to Furrer and Skinner (2003:41), the engagement principle refers to ' ... active, goal-directed, flexible, constructive, persistent, focused interactions with the social and physical environments'. This sense of relatedness (engagement) plays a crucial role in learners' academic engagement and performance; and forms a good predictor of the learners' long-term academic achievement and school completion (Anderson, Christenson, and Lehr 2004; Certo et al. 2003; Furrer and Skinner 2003).

In a school which is committed to fostering pastoral care and a sense of belonging, learners who do not meet expectations will receive support and opportunities to learn how to interact (Gaffney et al. 2004). This support involves interventions that not only promote the well- 
being of the learners, but also addresses the needs of the individual learner, and, possibly, his/her family (Eber et al. 2002; McCurdy et al. 2003; Nelson et al. 2002).

\section{Context of the study}

South Africa replaced its pre-1994 (apartheid) craft-knowledge teacher education model in 2000 with the reflective-adaptive model of teacher education (Ezer, Gilat, and Sagee 2010; Republic of South Africa 2011). In 2005, a module dealing with the pastoral role of the educator was introduced as part of the Postgraduate Certificate of Education (PGCE) programme in the institution under study. For the first time, student teachers who enrolled in the programme were trained to specifically address the issues which are associated with their pastoral role. The module is a core module which aims to equip the prospective teachers with the necessary knowledge, skills, beliefs and values pertaining to various cross-curricular themes, guidance and intervention. The module comprises a theoretical and a practical component. The theoretical component of the module entails lectures in a study guide dealing with cross-curricular themes such as cultural diversity, integrated schools, human rights and inclusivity education, religion, citizenship education, barriers to learning, child abuse and HIV/Aids. Practical guidance and intervention skills are also explored and applied in an essay-type assignment. During discussion classes, guidance skills are demonstrated. The practical component of the module entails the watching of pastoral care activities during teaching practice, and the completion of a form to confirm the student teacher's observation of pastoral care activities.

\section{Empirical study}

A non-experimental survey research design involving quantitative data was utilised to generate data for the study of the student teachers' opinion on the competencies they obtain from the module.

\section{Sampling}

Non-probability convenience sampling was used. The sampling frame consists of all Subject didactics History $(n=56)$ and Learning area didactics Social Sciences $(n=122)$ students who enrolled for the pastoral role module. The questionnaire was group-administered to 59 (33.1\% of the target population of 178) student teachers. The sample included sub-groups of race, gender, age, geographical area, academic qualifications and teaching practice experience. White and Black as well as male and female students between the ages of 24 to 55 years were included. Respondents were from the following six geographical areas: Gauteng, Mpumalanga, North West, KwaZulu-Natal, the Free State and Limpopo. The respondents had all obtained a first bachelors' degree. Some of the respondents had also completed honours and/or masters' degrees. The teaching practice experience of the students varied from none to ten weeks.

\section{Data-collection method}

The questionnaire used to determine the student teachers' opinion regarding the knowledge, skills, beliefs and values they obtain from the module was based on Lang's (1995) discursive analysis of how to prepare teachers for pastoral care and personal and social education (either to be trained or to be educated), and Pattie's (2000) research project on personal and social 
education and teacher development in Hong Kong. These two scholars indicated that student teachers, in the preparation for their pastoral care role, needed to be educated in three distinct aspects, namely beliefs and values, knowledge and skills. The questionnaire comprised four scaled questions, each with a list of related variables to which the respondents were asked to respond (see Tables 1 to 3 for the listed variables). The four scaled questions included in the questionnaire were:

- $\quad$ What beliefs or values does the module help you to reflect on? (Question 1)

- What knowledge about your pastoral role do you gain from this module? (Question 2)

- $\quad$ What skills or professional competence do you obtain from this module? (Question 3)

- $\quad$ On the whole what aspects do you get the most from this module? (Question 4)

Respondents were asked to indicate, using a Likert-type scale, the strength of their agreement or disagreement regarding the extent to which the variables of each question contributed to the preparation for their pastoral care role by marking an $\mathrm{X}$ on a continuous scale ranging from SA, indicating strong agreement (6), to SD, indicating strong disagreement (1). The response rate for the questionnaires was $69 \%(\mathrm{~N}=41)$. During the data entry stage, it became clear that some respondents experienced difficulties in reading and understanding the instructions and the questions. This could affect the validity of the data, thus, eventually only $51 \%(\mathrm{~N}=30)$ of the completed questionnaires were used in the research project.

\section{Ethical considerations}

The following ethical principles were negotiated with the respondents prior to the start of the data-collection procedure, namely anonymity, voluntary participation, confidentiality and the possible feedback of important research findings to the sample group after the conclusion of the study.

\section{Results and discussion}

The data obtained from the questionnaires was assessed through statistical analysis, using the computerised data analysis software package Microsoft Excel. A mean score of 3.5 or greater was interpreted by an overall positive opinion of a given variable, and a mean score of less than 3.5 was indicative of an overall negative opinion of a given variable. The results from the questionnaires are presented in Tables 1 to 4.

\section{Table 1 in here}

Table 1 summarises the rank order, percentage, mean score and standard deviation of the student teachers' opinion on the beliefs and values that the module helps them to reflect on. The student teachers $(\mathrm{N}=30)$ who were sampled ranked the seven variables of the beliefs and values that the module help them to reflect on in the following numerical order. Of the 30 student teachers, 25 (83.3\%) ranked teacher-learner relationship as 1; 22 (73.3\%) ranked teacher open-mindedness as 2; 19 (63.3\%) ranked teacher responsibility as 3; 15 (50.0\%) ranked learner changeability as 4; $14(46.6 \%)$ ranked whole-school approach or team work as 5; $8(26.6 \%)$ ranked the pedagogy as 6 ; and $5(16.6 \%)$ saw teacher self-esteem as 7 . The majority of sampled student teachers see six 
of the seven variables as positive, because the mean scores for six variables were greater than 3.5: teacher-learner relationship $(\mathrm{m}=5.39)$; teacher open-mindedness $(\mathrm{m}=5.08)$; teacher responsibility $(\mathrm{m}=4.81)$; learner changeability $(\mathrm{m}=4.48)$; team work $(\mathrm{m}=4.28)$ and pedagogy $(m=3.84)$. The student teachers see the variable teacher self-esteem as a negative, because the mean score for the variable was less than 3.5, namely 3.21.

The first question of the questionnaire focused on the beliefs and values that the module helped the student teachers to reflect on. The majority of the student teachers indicated that six (teacher-learner relationship, teacher open-mindedness, teacher responsibility, learner changeability, teamwork and pedagogy) of the listed seven variables helped them to reflect on their own beliefs and values (open-mindedness, responsibility), those set out in the education policy documents (pedagogy) and those practiced in their teaching practice schools (teacherlearner relationship, learner changeability and team work). They were of the opinion that the module did not accommodate the development of their self-esteem as teachers sufficiently. The importance of developing the student teachers' self-esteem is crucial to the learning environment in their classrooms, their specific teaching-learning strategies and the development of the learners' self-esteem. According to Anderson et al. (2004) and Maples (1999), the notion of "caring for the carer", which includes both the personal and professional needs of teachers, should be included in all pre-service teacher education programmes.

The response of the student teachers' to the first question of the questionnaire was shaped by their own personal belief and value system, and the belief and value system as set out in the national education policy documents and practiced in their teaching practice schools. Within the South African context, for many of the student teachers the above belief and value systems are not always the same. They are respectively based on the student teachers' own cultural systems (African, White, Coloured and Indian); and the principles enshrined in the national education policy documents. Principles such as social transformation, active and critical learning, high knowledge and skills, progression, human rights, inclusivity, environment and social justice, valuing indigenous knowledge systems and credibility, validity and efficiency (Department of Basic Education 2011). The above will influence the student teachers' attitudes towards and involvement in the pastoral care of the learners during their subject teaching.

Table 2 in here

Table 2 summarises the rank order, percentage, mean score and standard deviation of student teachers' opinion on the knowledge they gained from the module. The student teachers $(\mathrm{N}=30)$ who were sampled ranked the eight variables in the following numerical order. Of the 30 student teachers, 25 (83.3\%) ranked pastoral care concepts as 1; 21 (70.0\%) ranked learners' sociocultural context as 2; 19 (63.3\%) ranked implementation of pastoral care as 3; 17 (57.0\%) ranked the class teachers' role as $4 ; 15$ (50.0\%) ranked barriers to learning as 5; $14(47.0 \%)$ ranked social relations as 6; 13 (43.0\%) ranked adolescent development as 7; and 12 (40.0\%) ranked ethical commitments as 8. The majority of sampled teachers are of the opinion that six of the eight variables help them to obtain the necessary knowledge for their future pastoral care role, because the mean scores of six of the eight variables were greater than 3.5: pastoral care concepts $(\mathrm{m}=5.39)$; learners' socio-cultural context $(\mathrm{m}=5.02)$; implementation of pastoral care $(\mathrm{m}=4.81)$; class teachers' role $(\mathrm{m}=4.52)$; barriers to learning $(\mathrm{m}=4.48)$; social relations $(\mathrm{m}=4.28)$. The student teachers are of the opinion that the module does not provide them with knowledge of adolescent development and ethical commitments. They see these two variables as negative, 
because the mean scores of the two variables were less than 3.5, namely 2.97 and 2.81 respectively.

For the second question of the questionnaire, the focus was on the knowledge that the student teachers gained from the module. With an ever-changing South African socio-cultural, gender and economic context, the caring and relational roles of teachers become even more important. The sampled student teachers were of the opinion that six (pastoral care concepts and implementation, learners' socio-cultural context, the class teacher's role, barriers to learning and social relations) of the eight variables provided them with knowledge of the content and the context of the pastoral care role. They were of the opinion that the module did not provide them with sufficient knowledge of adolescent development and ethical commitments. For their role as pastoral carers, they need knowledge of among others: the psychological development stage of adolescents (identity versus role confusion); the health and social well-being of learners; and their ethical commitments to others (teachers, learners and parents) and the guidance role to assist learners with problems.

Dobson (1996) and Reisby, Kryger, Moose, and Reinsholm (1994) highlight the importance of the social and cultural context in the implementation of pastoral care. The impact of among others cultural pluralism, the dissolution of traditions and norms, and the changing social contexts (high knowledge and skills, social transformation and environment and social justice) are all important elements in affecting the learners' academic engagement and performance. Furer and Skinner (2003) and Reisby et al. (1994) propose that the content as well as the context of teaching must be relevant. They argue that for the student teachers to carry out their pastoral care role successfully within a changing context, they need to be open-minded, aware of their own values, and have knowledge of adolescent development and the social relationships within and outside of the classroom. They also need knowledge to encourage open dialogue and cooperation with all role-players in terms of the learners' barriers to learning, and the ethical standards that they should adhere to when working for the general good of the learners, their parents and the community.

Table 3 in here

Table 3 summarises the rank order, percentage, mean score and standard deviation of student teachers' opinion on the skills or professional competence that the module helps them to obtain. The student teachers $(\mathrm{N}=30)$ who were sampled ranked the 11 variables in the following numerical order. Of the 30 student teachers, 24 (80.0\%) ranked communication skills $1 ; 19$ (63.0\%) ranked guidance skills 2; 18 (60.0\%) ranked empathy 3; 16 (53.0\%) ranked listening skills, expressing and recognising feelings and confidentiality 4; 15 (50.0\%) ranked reference skills 5; 14 (47.0\%) ranked crisis management skills 6; 13 (43.0\%) ranked open dialogue 7; 11 (37.0\%) ranked cooperation skills 8; 6 (20.0\%) ranked administration skills 9 . The majority of sampled student teachers see 10 of the 11 variables as positive, because the mean scores of these ten variables were greater than 3.5: communication skills $(m=5.37)$; guidance skills $(m=4.81)$; empathy $(\mathrm{m}=4.79)$; listening skills $(\mathrm{m}=4.52)$; expressing and recognising feelings $(\mathrm{m}=4.52)$; confidentiality $(\mathrm{m}=4.52)$; reference skills $(\mathrm{m}=4.48)$; crisis management skills $(\mathrm{m}=4.30)$; open dialogue $(\mathrm{m}=4.09)$; cooperation skills $(\mathrm{m}=3.82)$. The student teachers see the variable administration skills as negative, because the mean score of this variable was less than 3.5, namely 3.02. 
The third question of the questionnaire dealt with the skills or professional competence the module helped the student teachers to obtain. The majority of the sampled student teachers confirmed that 10 (communication, guidance, empathy, listening, expressing/recognising feelings, confidentiality, reference, crisis management, open dialogue and cooperation) of the 11 variables helped them to obtain the skills or professional competence that they need for their future pastoral care role. However, $20 \%$ of the student teachers indicated that they did not acquire the basic administration skills for their pastoral care role. Administration skills such as the writing of reports and remarks, the monitoring of attendance, and the maintaining of discipline are, according to Reisby et al. (1994), the prime skills for managing the pastoral care load in the classroom.

Reisby et al. (1994) indicate that the teacher's pastoral care role entails caring for the health and social aspects in the lives of the learners. However, the teacher will not only have to work with the individual learners, but also with their parents. One of the key roles of the educator as a pastoral carer is to be a coordinator between teachers, learners and parents. The latter is confirmed by Leung and Wong (1997). They highlight the importance of educating student teachers in writing reports and remarks, meeting parents, and giving guidance to learners, especially to learners with emotional problems. Easton (1995) and Wong (1993) highlight the importance of developing guidance skills for teachers. Best (1990) and Easton (1995) address the need of the student teachers to understand the individual and organisational obstacles involved in guidance, the issues related to the whole-school approach, ethical considerations such as confidentiality, and the relation between teachers and other role-players such as registered educational psychologists. Leung and Wong (1997) demonstrate that the pastoral care responsibilities of the teacher is often not clearly defined and structured, and that the subject teacher as pastoral educator often faces problems in terms of a lack of guidelines, supervision, time and support from the school.

\section{Table 4 in here}

Table 4 summarises the rank order, percentage, mean score and standard deviation of student teachers' opinion of the total sample $(\mathrm{N}=30)$ of the aspects they got most from the module. The student teachers who were sampled ranked the three aspects in the following numerical order. Of the 30 student teachers, 28 (93.0\%) ranked knowledge as 1; 27 (90.0\%) ranked beliefs and values as 2; and $26(87,0 \%)$ ranked skills as 3 . The above does not add up to $100 \%$ because some student teachers viewed two or all three aspects as equally important. The majority of sampled teachers see all three aspects as positive, because the mean score of the three aspects were greater than 3.5, knowledge $(m=5.62)$, beliefs and values $(m=5.49)$ and skills $(m=5.39)$.

From the student teachers' responses to the fourth question of the questionnaire, namely what aspects (beliefs and values, knowledge and skills) they got most from the module, the students ranked knowledge first (93\%), reflection on beliefs and values second (90\%), and skills third (87\%). All of them experienced the three aspects as positive and valuable to their future pastoral care role. In the preparation of student teachers for their pastoral care role all three aspects are to be considered as important. However, the most important of these three aspects is, according to Reisby et al. (1994), the attitudinal aspects (beliefs and values), because a positive attitudinal change towards the pastoral role will result in the student teachers being committed to the pastoral care of the learners in their class. 
The final question of the questionnaire focused on the developmental needs of student teachers in relation to the facilitation of learners' academic engagement and performance. Lang (1995) and Pattie (2000) emphasise that in the preparation of student teachers for the pastoral care aspects of their teaching responsibilities, three distinct aspects are important, namely attitudes and beliefs, knowledge and understanding, and skills and competence. It is necessary to develop the student teachers' awareness of their own attitudes and their schools' attitudes to pastoral care, and skills in group discussion, guidance, curriculum planning (aims, content, teaching and learning strategies, resources, evaluation) and working with parents and other roleplayers. The skills and competence also include individual guidance skills and skills in managing effective group discussion. Knowledge and understanding of their pastoral care role and responsibilities are required from student teachers in terms of their subject-related teaching and learning responsibilities, particularly in the system in which they work.

\section{Conclusion}

The pastoral care module addresses one of the seven roles of the reflective-adaptive model of teacher education. The student teachers were of the opinion that the pastoral care module instilled in them some of the knowledge, skills, beliefs and values that they might need for their future pastoral care responsibilities.The pastoral care role of teachers requires a wide range of knowledge, skills, beliefs and values; many of which may also be useful in the academic role that they have to fulfill. The redefinition of the teacher's academic and pastoral roles is a national priority, given the challenged circumstances of the learners from the poor inner city and rural communities. Some of the characteristics of the whole-school approach to pastoral care such as: the teacher-learner relationship, teacher responsibility, learner changeability, team work, the class teacher's role, empathy, the learners' socio-cultural context, barriers to learning and support, were identified in the module. For the module to be redefined towards a whole-school approach to pastoral care, the following aspects should be added to the learning outcomes of the module: the fostering of positive attitudes in learners through the quality of teaching and learning in a school subject; the monitoring of the learners' overall progress (academic, personal and social); the establishing of positive, supportive and collaborative relationships amongst the learners, teachers and parents; and the implementing of specific pastoral and support systems, extra-curricular activities and school ethos. A redefinition of the module in terms of the wholeschool approach to pastoral care will result not only in an integration of the teacher's pastoral role, the academic curriculum and the structural organisation of the school, but also to meet the personal and social needs of all learners to raise their academic performance, increase the throughput rate and advance the human capital development in South Africa.

\section{The way forward}

What kind of education does pre-service teachers at the institution under study need if they are to perform their redefined academic and pastoral roles constructively together? In the short term, the pastoral care module will have to be revisited, and a learning unit such as "Learning to teach: History and pastoral care" will have to be added to the study material. The following five sections, grounded in Best’s (2002) model of pastoral care, will be included in the learning unit: 
- $\quad$ The first section of the learning unit (the developmental pastoral curriculum) will be an introductory section dealing with the historical development of pastoral care in schools; the issue of the academic/pastoral divide in the classroom; and the new responsibility of teachers in this regard - the integration of their academic and pastoral roles in the classroom.

- $\quad$ For the second section of the learning unit (the promotion and maintenance of an orderly, supportive environment), the focus will be on the whole-school approach to pastoral care with special reference to the definition of the concept pastoral care, and the what and how of the whole-school approach. Case studies will also be included to sensitise the student teachers to the advantages and disadvantages of the different approaches (individual development-process and whole-school) to pastoral care.

- In the third section of the learning unit (the proactive, preventative pastoral care), the needs-focused model to pastoral care will be outlined. All three aspects of the model (pastoral case work, curriculum and control) will be included. Many of the skills (observational, interpersonal, listening and assessment) associated with guidance will be explained and illustrated using practical examples. The teaching skills (group work, handling of discussions, case studies, role-play and social discussions) applicable to the pastoral curriculum will also be described and demonstrated using practical classroom examples.

- $\quad$ The fourth section of the learning unit (the reactive pastoral case work), will include an assignment dealing with a pastoral case study taken from a typical classroom situation. It is the case study of Sipho, a well-behaved and academically gifted Grade 10 learner from a single parent family and rural school located 50 kilometers outside of Polokwane in the Limpopo province. The mother of the learner has fallen ill and was identified with HIV/Aids. Suddenly Sipho’s marks dropped; and he became involved in verbal bullying. As future pastoral carers, the student teachers will be requested to design an intervention plan for Sipho using the whole-school approach to pastoral care. They will have to include the following two aspects in their response to the problem: background to the problem (mother's health and well-being, stress and anxiety, forms of bullying, measuring bullying) and guidance (response to bullying, study skills, spiritual and moral development, teacher, peer and community support).

- $\quad$ In the fifth section of the learning unit (the reactive pastoral care), the student teachers will have to complete and submit a teaching practice dialogue journal of pastoral care cases they observed during teaching practice. The dialogue journal will be included in their teaching practice portfolios for their year-end promotion marks.

Finally, it can be concluded that the education of prospective teachers in higher education institutions involves two sides of a school: the pastoral side which provides a caring nurturing environment in which learners are meant to grow as individuals; and the academic side, which facilitates the teaching and learning of school subjects. Globally, higher education institutions provide some form of education for pastoral care, but the commitment, enthusiasm, structure, content and methodology differ from country to country (Hearn et al. 2006; Lodge 2006; Republic of South Africa 2011; Scott 2005; Watkins 1999). According to Mann (2006), it is important to note that pastoral care is not the destination in itself, but the nourishment for the journey, or the "oil of learning". Therefore, it has to be a major focus area of all teacher education programmes, because all newly qualified teachers who are entering the profession will be involved with pastoral care. The review of the international literature (Best 1990; Clark 2008; 
Eacute and Esteve 2010; Nadge 2006) revealed that there exists a strong link between learners' sense of self-worth, social and emotional well-being, enthusiasm for learning and optimism for the future; and that teachers worldwide are expected to provide supportive and nurturing contexts for the intellectual, physical, social, moral, spiritual and aesthetic development of learners. The empirical case study reported in this article revealed that the student teachers are of the opinion that if they as newly qualified teachers are to feel as confident to perform their pastoral care duties as adequately as their academic responsibilities, they need the necessary foundational, practical and reflexive competencies of the pastoral care role to help them to deal with the learners who are experiencing problems in school. It was argued in this study, that Best's (1990, 2002) needs-focused model is the most appropriate model to instill in student teachers the applied competences of the pastoral role.

The culture of the subject teacher as a pastoral carer, and the fostering of teachers' positive attitudes towards and commitment to both pastoral care (teacher as pastoral carer) and the achievement of educational outcomes (teacher as subject specialist) can be promoted worldwide by:

- alleviating the perceived academic/pastoral divide through an alignment of the pastoral and academic domains within a school in a structural (enabling structures) and cultural (enabling culture) sense. The structure of the school should emphasise the teacher's dual roles as a multiplicity of responsibility rather than two separate roles, and a shared understanding of the role of all teachers as pastoral carers in support of the alignment. Beyond the structural arrangement in the school, the integration of the two domains should be promoted by the culture of the school which includes its values, beliefs and norms in terms of pastoral care.

- exposing teacher educators, practicing teachers and student teachers to the issue of the academic/pastoral divide in the classroom by including it as a sub-theme in international conference programmes and proceedings, and devoting special issues of academic journals to the topic. Colleges or schools of education can also consider subscribing to the international journal Pastoral Care in Education which publishes theoretical, empirical and professional articles on the topic.

- implementing special awareness campaigns, internationally and nationally, to promote or "sell" the advantages of integrated planning for pastoral care to all in-service teachers to sensitise them to meet the personal, emotional, social and academic needs of learners through a pastoral care approach which is integrated in the academic curriculum and the structural organisation of the school. The purpose of the campaign is to ensure that all qualified teachers practice effective pastoral care in their classrooms, and improve the learners' academic engagement and performance and throughput.

This was an exploratory study. In a final follow-up research project, the following topic will be explored: The nurturer professional model of teacher education and support for learners in challenged contexts.

\section{Notes on contributor}

Sonja Schoeman is a full professor in the Department of Curriculum and Instructional Studies at the University of South Africa. Her research focuses on teacher education, pastoral care, education feminism and History and Social Sciences Didactics. 


\section{References}

Anderson, A., S. Christenson, and C. Lehr. 2004. Check and Connect: The importance of relationships for promoting engagement with school. Journal of School Psychology 42, no. 2: $95-113$.

Best, R. 1990. Pastoral Care in Schools: Some implications for Teacher Training. Australian Journal of Teacher Education 15, no. 1: 14-23.

Best, R. 2002. Pastoral care and personal social education. http://www.bera.ac.uk/pdfs/BESTPastoral care\&PSE.pdf. (Accessed on 2 May 2012).

Best, R. and P. Lang. 1995. Care and Education: The comparative perspective. In Caring for children: International Perspectives on Pastoral Care and PSE, ed. P. Lang, R.E. Best, and A. Lichtenberg, 3-12. New York: Cassell.

Centre for Adolescent Health. 2002. The Gatehouse Project: Promoting Emotional Well-Being: Team Guidelines for Whole School Change. Western Australia: Centre for Adolescent Health.

Certo, J., K. Cauley, and C. Chafin. 2003. Students' perspectives on their high school experience. Adolescence 38, no. 1\&2: 705-724.

Chidester, D. 2006. Religion Education in South Africa: Teaching and Learning about religion, Religions, and Religious diversity. British Journal of Religious Education 25, no. 4: $261-278$.

Clark, K.E. 2008. The pastoral academic divide: Impacts and implications for pastoral care. Master of Education thesis. Murdoch University, Perth, Western Australia.

De Jong, T. and H. Kerr-Roubicek. 2007. Towards a Whole School Approach to Pastoral Care: A Proposed Framework of Principles and Practices. Australian Journal of Guidance \& Counselling 17, no. 1: 1-12.

Department of Basic Education. 2011. Curriculum and Assessment Policy Statement (CAPS). Pretoria: Government Printer.

Department of Education. 2003. National Curriculum Statement Grades 10-12 (General History). Pretoria: Government Printer.

Dobson, B. 1996. The Contribution of TACADE’s Skills Programmes to the Personal and Social Development of Secondary School Students. Pastoral Care in Education 14, no. 1: $12-16$.

Doig, C. 2000. Quality the Richmond way: Developing a successful behaviour management programme. Wellington: New Zealand Council for Educational Research.

Eacute, J. and M. Esteve. 2010. The Transformation of the Teachers' Role at the End of the Twentieth Century: New Challenges for the Future. Educational Review 52, no. 2: 197207. 
Easton, S. 1995. Counselling Skills for Teachers in Secondary Schools: Observations from One Day Workshops. Pastoral care in Education 14, no.1: 25-28.

Eber, L., G. Sugai, C. Smith, and T. Scott. 2002. Wraparound and positive behavioural interventions and supports in the school. Journal of Emotional and Behavioural Disorder 10, no. 3: $171-180$.

Ezer, H., I. Gilat, and R. Sagee. 2012. Perceptions of teacher education and professional identity among novice teachers. European Journal of Teacher Education 33, no. 4: 391-404.

Fredericks, J., P. Blumenfeld, and A. Paris. 2004. School engagement: Potential of the concept, state of the evidence. Review of Educational Research 74, no. 1: 59—96.

Furrer, C. and E. Skinner, 2003. Sense of relatedness as a factor in children's academic achievement and performance. Journal of Educational Psychology 95, no. 1: 148-162.

Gaffney, M., J. McCormack, N. Higgins, and N. Taylor. 2004. Improving school culture: What we learned from three primary schools. Kairaranga 5, no. 2: 36-43.

Hearn, L., R. Campbell-Pope, J. House, and D. Cross. 2006. Pastoral care in education. Child Health Promotion Research Unit. Perth: Edit Cowan University.

Hui, E.K.P. 2002. A whole-school approach to guidance: Hong Kong teachers' perceptions. British Journal of Guidance \& Counselling 30, no. 1: 63-80.

Hunter-Gault, C. 2008. Apartheid Inequalities Linger in South African Schools. http://www.npr.org/templates/story/story. (Accessed on 15 January 2012)

Lang, P. 1995. Preparing Teachers for Pastoral Care and Personal and Social Education: to Train or Educate? Pastoral Care in Education 13, no. 4: 18-23.

Leung, M.K. and K.P. Wong. 1997. A Study of the Role and Duties of Form Teachers at Secondary 1 to 3 Levels in Hong Kong Secondary Schools. A paper presented at the Hong Kong Research Association. 14 ${ }^{\text {th }}$ Annual Conference, the Chinese University of Hong Kong. 15 to 16 November 1997.

Lodge, C. 2006. Beyond the head year. Pastoral Care in Education 24, no. 1: 4—9.

Mann, B. 2006. An invitation to a journey in leadership. Unpublished monograph.

Maples, M.F. 1999. Teachers need self-esteem too: a counselling workshop for elementary school teachers. Elementary School Guidance and Counselling 27, no. 1: 33-38.

Marland, M. 1974. Pastoral care. London: Heinemann.

McCurdy, B.L., M. Manella, and N. Eldridge. 2003. Positive behaviour in urban schools. Journal of Positive Behaviour Interventions 5, no. 3: 158-170.

Ministry of Education. 2007. Target setting for quality education - statement by Western Cape Education MEC Cameron Dugmore. Cape Town: News Archive. 
Nadge, A.J. 2005. Academic care: Building resilience, Building futures. Pastoral care in Education 23, no. 1: 8-33.

Nelson, J.R., R.M. Martell, and N. Marchand-Martella. 2002. Maximising student learning: The effects of a comprehensive school-based programme for preventing problem behaviours. Journal of Emotional and Behavioural Disorders 10, no. 3: 136-148.

Osterman, K.F. 2000. Students' need for belonging in the school community. Review of Educational Research 70, no. 3: 323-364.

Pattie, L.F.Y.Y. 2002. Personal and Social Education and Teacher Education in Hong Kong. Pastoral Care in Education 18, no. 2: 42-46.

Phurutse, M.C. 2005. Factors Affecting Teaching and Learning in South African Public Schools. Cape Town, ZA: HSRC press.

Reisby, K., N. Kryger, L. Moose, and L. Reinsholm. 1994. The Tasks of the Class Teacher: Tradition and Renewal - an evaluation of development projects carried out in the Danish Folkeskole. Pastoral Care in Education 12, no. 1: 27-33.

Republic of South Africa. 2011. National Qualifications Framework Act 67 of 2008. Policy on the minimum requirements for Teacher Education Qualifications. Pretoria: Government Printer Works.

School visits. 2011. Personal experience.

Scott, B. 2005. Getting to the heart of the matter: Examining the efficacy of a whole-school approach to behaviour management. Kairaranga 6, no. 1: 20-34.

Watkins, C. 1999. Changing structures for caring and learning. Pastoral Care in Education 17, no. $4: 1-2$.

Wong, S.P. 1993. Interpersonal Skills for Teachers in Hong Kong. Chinese University of Hong Kong Journal of Primary Education 4, no. 1: 67-71.

Table 1. Rank order, percentage, mean score (M) and standard deviation (SD) of student teachers' opinion by means of total sample $(n=30)$ of the beliefs and values the module helps them to reflect on

\begin{tabular}{lccccc}
\hline Variable & Rank & N & $\%$ & M & SD \\
\hline Teacher-learner relationship & 1 & 25 & 83.3 & 5.39 & 0.85 \\
Teacher open-mindedness & 2 & 22 & 73.3 & 5.08 & 1.13 \\
Teacher responsibility & 3 & 19 & 63.3 & 4.81 & 1.05 \\
Learner changeability & 4 & 15 & 50.0 & 4.48 & 1.08 \\
Team work & 5 & 14 & 46.6 & 4.28 & 1.31 \\
Pedagogy & 6 & 8 & 26.6 & 3.84 & 1.12 \\
Teacher self-esteem & 7 & 5 & 16.6 & 3.21 & 1.35 \\
\hline
\end{tabular}


Table 2. Rank order, percentage, mean score (M) and standard deviation (SD) of student teachers' opinion by means of total sample $(n=30)$ of the knowledge they gained from the module

\begin{tabular}{lccccc}
\hline Variable & Rank & N & $\%$ & M & SD \\
\hline Pastoral care concepts & 1 & 25 & 83.3 & 5.39 & 0.85 \\
Learners' socio-cultural context & 2 & 21 & 70.0 & 5.02 & 1.62 \\
Pastoral care implementation & 3 & 19 & 63.3 & 4.81 & 1.05 \\
Class teachers' role & 4 & 17 & 57.0 & 4.52 & 1.35 \\
Barriers to learning & 5 & 15 & 50.0 & 4.48 & 1.08 \\
Social relations & 6 & 14 & 47.0 & 4.28 & 1.31 \\
Adolescent development & 7 & 13 & 43.0 & 2.97 & 1.44 \\
Ethical commitments & 8 & 12 & 40.0 & 2.81 & 1.36 \\
\hline
\end{tabular}

Table 3. Rank order, percentage, mean score (M) and standard deviation (SD) of student teachers' opinion by means of total sample $(n=30)$ of the skills or professional competence the module helps them to obtain

\begin{tabular}{lccccc}
\hline Variable & Rank & $\mathrm{N}$ & $\%$ & $\mathrm{M}$ & $\mathrm{SD}$ \\
\hline Communication skills & 1 & 24 & 80.0 & 5.37 & 0.82 \\
Guidance skills & 2 & 19 & 63.0 & 4.81 & 1.05 \\
Empathy & 3 & 18 & 60.0 & 4.79 & 1.02 \\
Listening skills & 4 & 16 & 53.0 & 4.52 & 1.00 \\
Expressing/recognising feelings & 4 & 16 & 53.0 & 4.52 & 1.00 \\
Confidentiality & 4 & 16 & 53.0 & 4.52 & 1.00 \\
Reference skills & 5 & 15 & 50.0 & 4.48 & 1.08 \\
Crisis management skills & 6 & 14 & 47.0 & 4.30 & 1.15 \\
Open dialogue & 7 & 13 & 43.0 & 4.09 & 1.45 \\
Cooperation skills & 8 & 11 & 37.0 & 3.82 & 1.51 \\
Administration skills & 9 & 6 & 20.0 & 3.02 & 1.62 \\
\hline
\end{tabular}

Table 4. Rank order, percentage, mean score (M) and standard deviation (SD) of student History teachers' opinion by means of total sample $(n=30)$ of the aspects they got most from the module

\begin{tabular}{lccccc}
\hline Variable & Rank & N & $\%$ & M & \\
\hline Knowledge & 1 & 28 & 93.0 & 5.62 & 0.63 \\
Beliefs and values & 2 & 27 & 90.0 & 5.49 & 0.77 \\
Skills & 3 & 26 & 87.0 & 5.39 & 0.85 \\
\hline
\end{tabular}

